\title{
ESR1 Pvull polymorphism: from risk factor to prognostic and predictive factor of the success of primary systemic therapy in advanced breast cancer
}

Ramadhan Karsono ${ }^{*}$ (D), Samuel J. Haryono ${ }^{1}$, Bambang Karsono ${ }^{2}$, Wirsma Arif Harahap ${ }^{3}$, Yulia Pratiwi ${ }^{4}$ and Teguh Aryandono ${ }^{5}$

\begin{abstract}
Background: The ESR1 gene encodes Estrogen Receptor alpha (ERa), which plays a role in the tumourigenesis of breast cancer. A single nucleotide polymorphism (SNP) in intron 1 of this gene called ESR1 Pvull (rs2234693) has been reported to increase the risk of breast cancer. This study aimed to investigate the ESR1 Pvull polymorphism as a prognostic and predictive factor guiding the choice of therapy for advanced breast cancer.
\end{abstract}

Methods: This retrospective study was conducted in 104 advanced breast cancer patients at Dharmais Cancer Hospital from 2011 to 2018. The ESR1 Pvull polymorphism was analysed by Sanger sequencing of DNA from primary breast tumour samples.

Results: The percentages of patients with ESR1 Pvull genotypes TT, TC, and CC were 42.3, 39.4, and 18.3\%, respectively. Looking at prognosis, patients with ESR1 Pvull TC + CC had shorter overall survival than those with the TT genotype $[\mathrm{HR}=1.79 ; 95 \% \mathrm{Cl} 1.05-3.04 ; p=0.032]$. As a predictive marker, $\mathrm{TC}+\mathrm{CC}$ was associated with shorter survival $(p=0.041)$, but TC + CC patients on primary hormonal therapy had a median overall survival longer than TC $+C C$ patients on primary chemotherapy (1072 vs 599 days).

Conclusion: The ESR1 Pvull TC + CC genotypes confer poor prognosis in advanced breast cancer, but these genotypes could be regarded as a good predictor of the therapeutic effect of hormonal treatment.

Keywords: ESR1 Pvull, Breast cancer, Hormonal, Chemotherapy, Indonesia

\section{Background}

Breast cancer is the most common cancer in women and is a heterogeneous disease based on several molecular subtypes by immunohistochemistry, epidemiological risk, and response to treatment [1]. In each individual with breast cancer, there is a set of genetic aberrations

\footnotetext{
*Correspondence: ramadhan@dharmais-surgonc.com

1 Department of Surgical Oncology, Dharmais Hospital-National Cancer Center, Jakarta, Indonesia

Full list of author information is available at the end of the article
}

that can be informative in identifying their risk, choosing their therapy, and making a prognosis. Information on genetic aberrations in cancer will lead to more precise treatments [2].

Over two-thirds of breast cancers express estrogen receptor $\alpha$ protein (encoded by ESR1) which plays a role in the tumourigenesis of breast cancer [3, 4]. Recent, retrospective analyses of ESR1 mutations in circulating tumour DNA suggested that the occurrence of the mutations was associated with poor overall survival and resistance to hormonal treatment in patients with metastatic 
disease [5]. The majority of these mutations are located in exon 8, within the ligand-binding domain (LBD), and create a ligand-free constitutively activated ER, which has been associated with a worse outcome and could be considered a predictive marker guiding therapeutic decision making [6, 7].

An intronic polymorphism in the ESR1 gene (rs2234693), also called ESR1 PvuII, is associated with an increased risk of breast cancer and decreased estrogen receptor (ER) expression [3] Recent data from several studies have garnered interest in investigating the potential role of ESR1 mutational status as a predictive marker and a tool to guide clinicians in choosing therapies, but there are many limitations to developing predictive biomarkers [6]. In this study, we investigated ESR1 PvuII as a prognostic and predictive factor for the selection of therapy in advanced breast cancer.

\section{Methods}

\section{Study design and patients}

This was a retrospective study that included 104 consecutive advanced breast cancer patients who had been treated between 2011 and 2018 in Dharmais Cancer Center Hospital. Advanced breast cancer included both locally advanced disease (stage $3 \mathrm{~B}$ and $3 \mathrm{C}$ ) and metastatic breast cancer with distant metastases to other organs, commonly the skeleton, lung, brain, and liver [8]. Patients were included who met the inclusion criteria and had complete data on both tissue characteristics and follow-up status. Fresh tissue was taken before primary systemic treatment. Patients with complete treatment were those who were given primary hormonal therapy for 6 months or primary chemotherapy within 6 cycles.

Therapeutic options were chosen based on the treatment protocol in the NCCN guidelines [9]. The agents available to the primary hormonal therapy group were Aromatase Inhibitor (AI) and Tamoxifen for postmenopausal patients and premenopausal patients, respectively. The patients, received Tamoxifen only or bilateral salpingo-oophorectomy (BSO) plus AI/Tamoxifen, or if patients rejected $\mathrm{BSO}$ they were given Gonadotropin-Releasing Hormone Analogue (GnRHa) and AI/Tamoxifen for 6 months. The AI was Letrozole, Anastrozole, or Exemenestane.

The primary chemotherapy group received FAC (5-Fluorouracil, Adriamycin, and Cyclophosphamide) which was given for 6 cycles. In this study, patients with HER2+ cancer did not receive anti-HER2 agents. The patients provided written informed consent to participate in the study, which was approved by the Ethics Committee of Dharmais Hospital (ethical clearance numbers 049/PEP/08/2011 and 199/KEPK/XI/2019).

\section{Mutational analysis}

DNA samples from primary breast tumours were processed by Polymerase Chain Reaction (PCR) using the ESR1 forward primer TGT AAA ACG ACG GCC AGT TCA CGC AGT CTG GAG TTG TC and reverse primer CAG GAA ACA GCT ATG ACC AGA CCA ATG CTC ATC CCA AC. The total product was $519 \mathrm{bp}$, which was sequenced by Sanger sequencing with BigDye v3.1 reagent [Applied Biosystems]. Sequence data were analysed using Bioinformatics Software [Seqscape] and combined with clinicopathological data. The sequenced of ESR1 PvuII Polymorphism (Fig. 1) was divided into wild-type (TT variant), TC variant, and CC variant.

\section{Statistical analysis}

Statistical analysis was performed using IBM SPSS 21. Associations between ESR1 PvuII polymorphism and clinicopathological variables were assessed by the chisquare test ( $\chi^{2}$ test). All analyses were hypothesis-driven, and $P<0.05$ was considered statistically significant. Overall survival (OS) was defined as the time from diagnosis until death from any cause. OS rates were estimated using the Kaplan-Meier method. A Cox proportional hazards model was used to estimate the prognostic value of ESR1 PvuII Polymorphism on overall survival (OS). To estimate the predictive factor of genotypes on OS, hazard ratios (HRs) with 95\% confidence interval (CIs) were calculated for primary hormonal therapy vs. primary chemotherapy in the TT and TC + CC groups.

\section{Results}

Correlation of ESR1 Pvull genotype with survival Correlations type of ESR1 Pvull polymorphism with treatment effect and survival

In the TT group, patients who underwent primary hormonal therapy had a median OS of 1375 days ( $95 \%$ CI, 983-1766 days) compared with 951 days for patients who underwent primary chemotherapy (Fig. 3A). There was a significant difference in survival in the $\mathrm{TC}+\mathrm{CC}$ variant group (Fig. 3B), as these patients survived longer after primary hormonal therapy than primary chemotherapy (1072 vs. 599 days).

\section{Discussion}

Breast cancer in Indonesia, as in other developing countries, is disregarded and mostly diagnosed late, at stages 3 and 4, at which time the patient has a low life expectancy [10]. The persisting issue in a clinical setting of advanced breast cancer is the type of therapy give. Currently, oncologists routinely apply the clinical TNM staging system and detect the ER, progesterone receptor (PR), and 


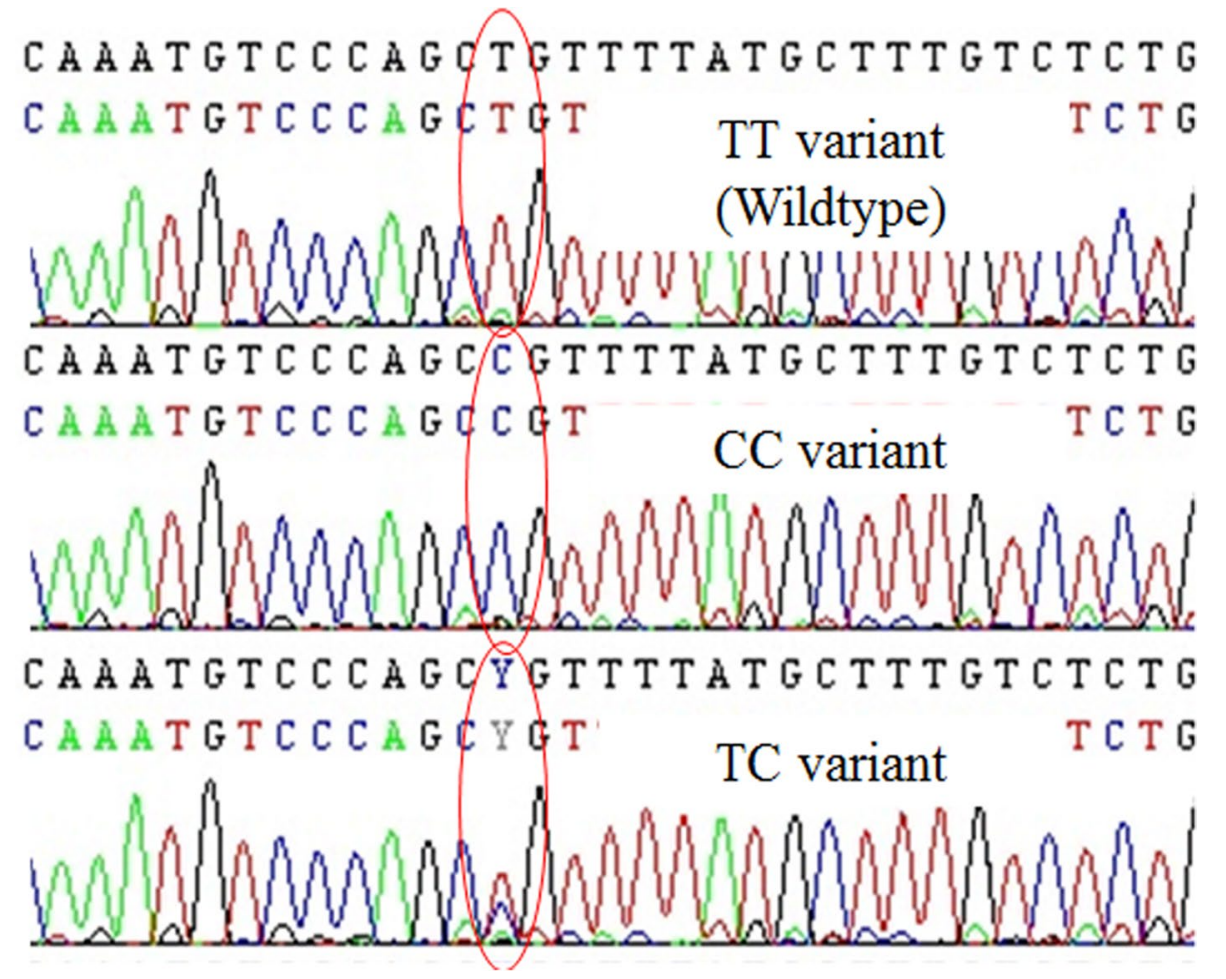

Fig. 1 The result of Sanger sequencing showing a different type of ESR1 Pvull Polymorphism. The red circle show the base change (Y is bioinformatics code for the presence of T or $\mathrm{C}$ )

Her2 proteins in the tumour cells [9]. Most clinicians tend to give chemotherapy as soon as possible and ignore the ER/PR as the hormonal status, whose expression remains the lead function in ER/PR positive cases, and but this approach seems to give no extra consideration to the underlying obstacles and benefits [11]. The Cochrane meta-analysis for advanced breast cancer showed no difference in survival between chemotherapy or hormonal therapy and chemotherapy worsened quality of life [12]. Our study found that there was a statistically significant difference survival between patients given hormonal therapy and patients given chemotherapy in the $\mathrm{TC}+\mathrm{CC}$ genotype group, where hormonal therapy yielded a longer survival than chemotherapy.

Only few prospective studies have compared primary chemotherapy with primary hormonal therapy in advanced breast cancer [12-17]. Treatment selection of advanced breast cancer is based on hormonal receptors at the protein levels rather than at the genotype level, according to the NCCN guidelines HR-positive patients will be given hormonal therapy whereas HR-negative or Her2+ and visceral metastasis patients will receive chemotherapy [9]. Chemotherapy for advanced stages hormone receptor-positive cases breast cancer with visceral metastasis and Her2+ positivity does not prolong life expectancy [12]. Severe side effects of chemotherapy have become a reason to minimize the administration this treatment to patients. A new parameter is needed that can predict which patients should receive chemotherapy or hormonal therapy.

ESR1 SNPs are associated with tumour carcinogenesis, cell proliferation, metastasis, and prognostic [1820]. Every woman with breast cancer has the ESR1 gene but in only $70-80 \%$ of breast tumours is ER $\alpha$ expressed, as shown by immunohistochemistry [21]. Several mechanisms have been shown to silence ER expression, such as ESR1 mutations, polymorphisms, epigenetic events, and posttranslational modification events [22, 23]. Immunohistochemical detection of hormone receptor expression is often a problem in clinical practice (Table 1) [24].

In general ESR1 PvuII (rs2234693) changes the proteins detectable in blood and has been used as an inherited risk factor for Asian people [25]. This paper does not discuss breast cancer risk factors, but we will discuss further how this SNP is present in tumour tissue and can be used as a predictor of the best therapy. This translational study is the first analysis of a novel genetic predictor that could help us choose between chemotherapy or 
Table 1 Correlations between ESR1 Pvull polymorphisms and clinicopathological features

\begin{tabular}{|c|c|c|c|}
\hline \multirow[t]{2}{*}{ Characteristics } & \multicolumn{2}{|c|}{ ESR1 Pvull Polymorphism } & \multirow[t]{2}{*}{$P$-value } \\
\hline & $\begin{array}{l}\text { TT genotype } \\
(n=44)\end{array}$ & $\begin{array}{l}\text { TC }+ \text { CC genotype } \\
(n=60)\end{array}$ & \\
\hline \multicolumn{4}{|l|}{ Age at biopsy } \\
\hline Mean ( \pm SD) & $47,5(9,5)$ & $48,1(10,9)$ & \multirow[t]{2}{*}{$0,779^{b}$} \\
\hline Median (range) & $48,5(28-68)$ & $47(22-75)$ & \\
\hline \multicolumn{4}{|l|}{ Grade } \\
\hline Low & $19(36,5)$ & $33(63,5)$ & \multirow[t]{2}{*}{$0,234^{\mathrm{a}}$} \\
\hline High & $25(48,1)$ & $27(51,9)$ & \\
\hline \multicolumn{4}{|l|}{ Hormonal Receptor } \\
\hline Negative & $9(34,6)$ & $17(65,4)$ & \multirow[t]{2}{*}{$0,359^{\mathrm{a}}$} \\
\hline Positive & $35(44,9)$ & $43(55,1)$ & \\
\hline \multicolumn{4}{|l|}{ ER (Estrogen Receptor) } \\
\hline Negative & $13(40,6)$ & $19(59,4)$ & \multirow[t]{2}{*}{$0,817^{\mathrm{a}}$} \\
\hline Positive & $31(43,1)$ & $41(56,9)$ & \\
\hline \multicolumn{4}{|c|}{ PR (Progesteron Receptor) } \\
\hline Negative & $13(41,9)$ & $18(58,1)$ & \multirow[t]{2}{*}{$0,96^{\mathrm{a}}$} \\
\hline Positive & $31(42,5)$ & $42(57,5)$ & \\
\hline \multicolumn{4}{|l|}{ Her2 status } \\
\hline Negative & $33(44,6)$ & $41(55,4)$ & \multirow[t]{2}{*}{$0,458^{\mathrm{a}}$} \\
\hline Positive & $11(36,7)$ & $19(63,3)$ & \\
\hline \multicolumn{4}{|l|}{ Histology } \\
\hline Ductal & $41(43,6)$ & $53(56,4)$ & \multirow[t]{2}{*}{$0,407^{\mathrm{a}}$} \\
\hline Lobular & $3(30,0)$ & $7(70,0)$ & \\
\hline \multicolumn{4}{|l|}{ Therapy } \\
\hline $\begin{array}{l}\text { Primary hormonal } \\
\text { therapy }\end{array}$ & $24(54,5)$ & $29(48,3)$ & \multirow[t]{2}{*}{$0,531^{\mathrm{a}}$} \\
\hline Primary chemotherapy & $20(45,5)$ & $31(51,7)$ & \\
\hline
\end{tabular}

$P$ value: ${ }^{\mathrm{a}}=$ Pearson Chi Square; ${ }^{\mathrm{b}}=$ Independent sample T test hormonal therapy as the primary treatment for advanced breast cancer.

As a prognostic factor, the TT genotype was correlated with longer survival than the $\mathrm{TC}$ and $\mathrm{CC}$ genotypes (Fig. 2A \& B). The risk of death in the TC $+\mathrm{CC}$ genotype group was higher than that in the TT genotype group, and the highest risk of death was in the CC genotype subgroup (Table 2). Blood detectable ESR1 mutations in exon 8 after AI failure have been associated with a worse prognosis for overall survival than wild-type ESR1 [6, 26].

This study found a statistically significant difference between the survival of patients given different therapies in the TC $+\mathrm{CC}$ genotype group, where the hormonal therapy subgroup had a longer survival than the chemotherapy subgroup (Fig. 3B). Giving chemotherapy to the $\mathrm{TC}+\mathrm{CC}$ variant group brought a risk of death 2.01 times higher than giving hormonal therapy (Fig. 3B). These finding are in line with Kou's study, which found that the ESR1 PvuII rs2234693 T/T genotype vs. $\mathrm{C} / \mathrm{T}$ had a better OS when the patients were not given adjuvant chemotherapy [27]. This result is slightly different from others, which have shown that there are no specific benefits of chemotherapy or hormonal therapy in patients with circulating ESR1 exon mutated cells $[6,28]$.

ESR1 mutations in circulating tumour cells have been used as a predictive factor for breast cancer patients after failure of hormonal therapy [28]. One strength of the current study was genotyped ESR1 before applying the therapy to the primary tissue. The weakness of this study is that the results shown are still lacking in precision,

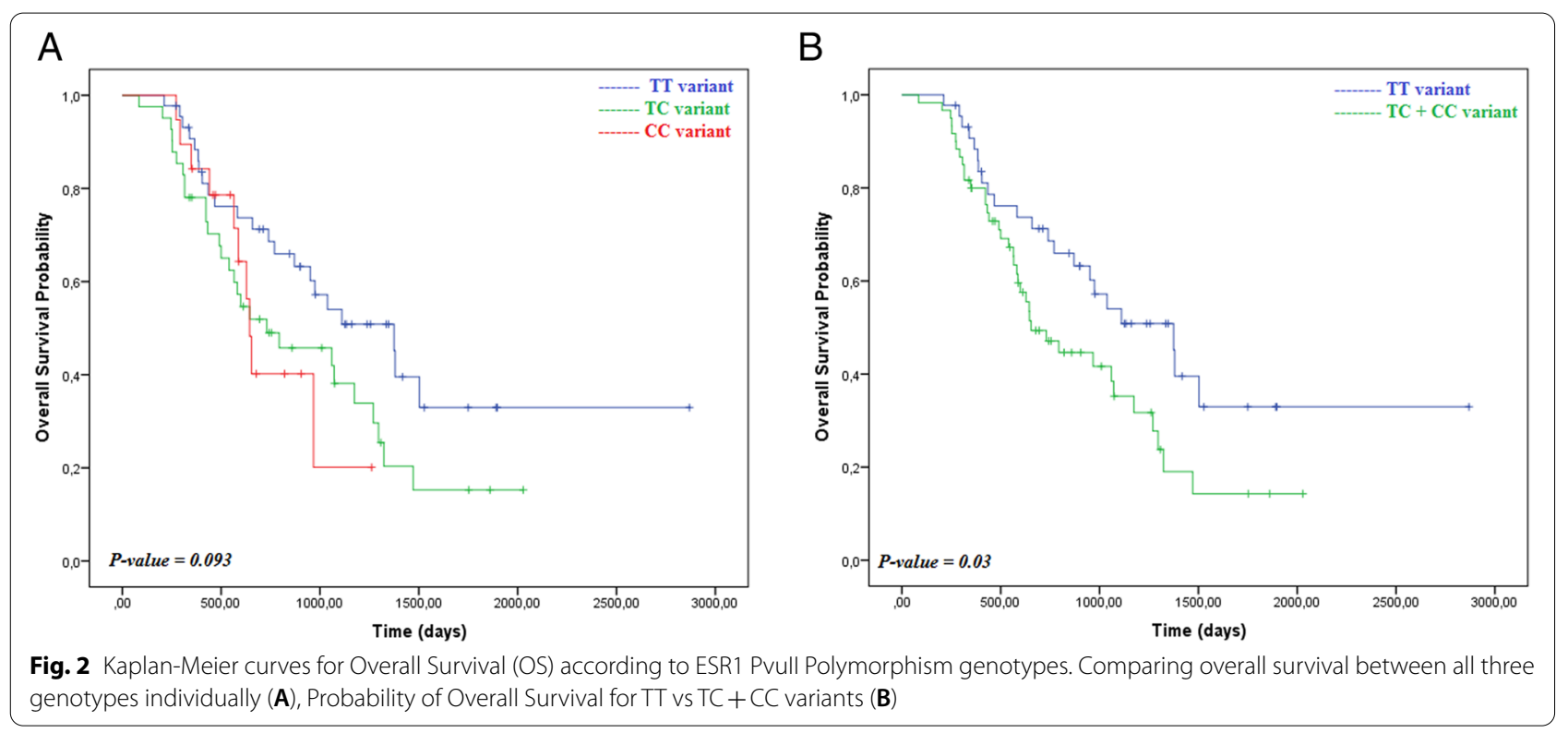


Table 2 Overall Survival by ESR1 Pvull polymorphism alleles

\begin{tabular}{llllll}
\hline Group & No. & Events & OS, Median $(\mathbf{9 5} \%$ Cl), days & Hazard Ratio (95\% Cl) & P-value \\
\hline TT variant & 44 & 22 & $1375(965-1784)$ & NA & $1.77(1.01-3.1)$ \\
TC variant & 41 & 28 & $730(237-1222)$ & $1.85(0.85-4.01)$ & 0.046 \\
CC variant & 19 & 10 & $644(601-686)$ & $1.79(1.05-3.04)$ & 0.117 \\
TC + CC variants & 60 & 34 & $654(449-858)$ & 0.032 \\
\hline
\end{tabular}

Abbreviation: NA not applicable

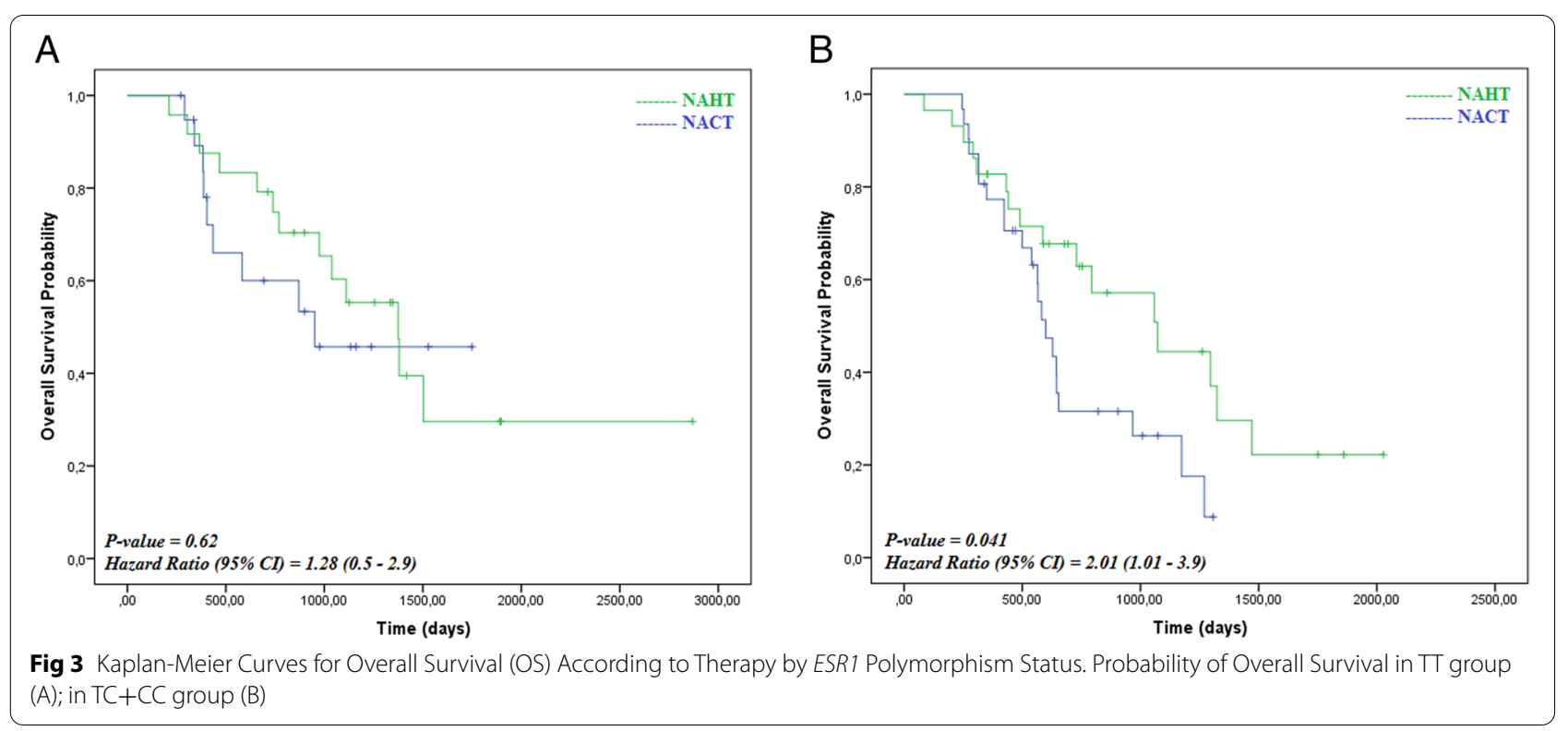

because confidence intervals (CIs) were quite wide and the number of samples was small, so it will be necessary to investigate these issues in a larger, prospective study. Further study of the mechanisms underlying the better prognosis of patients with different genotypes PvuII rs2234693 is warranted [27].

\section{Conclusion}

In general, $\mathrm{TC}+\mathrm{CC}$ variants have a worse prognosis than TT variants. However, hormonal therapy will provide a longer survival rate than chemotherapy to the former subgroup. Our analyses provide compelling evidence that ESR1 PvuII is a novel prognostic marker in breast cancer and is also highly predictive of anticancer therapy outcomes. It could become a predictive factor for first-line hormonal treatment outcomes because the genotype might predict which kind of therapy is expected to be more effective.

\section{Abbreviations}

Al: Aromatase inhibitor; BSO: Bilateral salpingo-oophorectomy; Cls: Confidence interval; ER: Estrogen receptor; FAC : 5-fluorouracil, adriamycin, and cyclophosphamide; GnRHa: Gonadotropin-releasing hormone analogue; HRs: Hazard ratios; LBD: Ligand binding domain; NA: Not applicable; NACT: Neoadjuvant chemotherapy; NAHT: Neoadjuvant hormonal therapy; OS: Overall survival; PCR: Polymerase chain reaction; PR: Progesterone receptor; SD: Standard deviation.

\section{Acknowledgements}

We would like to thank all staff in Research and Development Dharmais National Cancer Center Hospital, especially Fahreza Saputra, Dewi Kristanti, Didin Solachudin for technical laboratory assistance, and Dhira for helping write this manuscript.

\section{Authors' contributions}

R.K conceptualized and designed the study, and was a major contributor to data interpretation and manuscript writing. S.J.H, B. K, W.A.H, and T. A contributed manuscript writing. Y. P coordinated the data input and did a significant amount of the work on statistical analysis, data interpretation, and manuscript writing. All authors read, contributed to, and approved the final manuscript.

\section{Funding}

This study was funded by Dharmais National Cancer Center Hospital, Indonesia. The funding bodies played no role in the design of the study and collection, analysis, and interpretation of data and in writing the manuscript. 


\section{Availability of data and materials}

The datasets for this manuscript are not publicly available because they contain personal patient information and the data belong to the Dharmais Cancer Hospital. Requests for data must be directed to [Ramadhan Karsono, ramad han@dharmais-surgonc.com].

\section{Declarations}

\section{Ethics approval and consent to participate}

All procedures performed in studies involving human participants were performed per the ethical standards of the institution with written and verbal informed consent. The number of ethical clearances was 049/PEP/08/2011 and 199/KEPK/XI/2019 by Dharmais National Cancer Center Hospital. Hospital administrative permission is required to access raw data, this is included in the application for ethical approval. Ethical approval was given by the chairman and the ethics review team of Dharmais National Cancer Center Hospital, where this research was known and approved by the head of research and development and the main director of the hospital.

\section{Consent for publication}

Not Applicable.

\section{Competing interests}

The authors declare no conflict of interest.

\section{Author details}

${ }^{1}$ Department of Surgical Oncology, Dharmais Hospital-National Cancer Center, Jakarta, Indonesia. ${ }^{2}$ Department of Hematology and Medical Oncology, Dharmais Hospital-National Cancer Center, Jakarta, Indonesia. ${ }^{3}$ Surgical Oncology Division, Faculty of Medicine Universitas Andalas/Dr. M Djamil General Hospital Padang, West Sumatera, Indonesia. ${ }^{4}$ Functional Medical Staff of Surgical Oncology Department, Dharmais Hospital-National Cancer Center, Jakarta, Indonesia. ${ }^{5}$ Department of Surgery, Faculty of Medicine Public Health and Nursing, Universitas Gadjah Mada, Yogyakarta, Indonesia.

Received: 4 June 2020 Accepted: 5 December 2021

Published online: 20 December 2021

\section{References}

1. Goldhirsch A, Wood WC, Coates AS, Gelber RD, Thürlimann B, Senn H-J, et al. Strategies for subtypes--dealing with the diversity of breast cancer: highlights of the St. Gallen International Expert Consensus on the Primary Therapy of Early Breast Cancer 2011. Ann Oncol Off J Eur Soc Med Oncol [Internet]. 2011 Aug [cited 2019 Apr 15];22(8):1736-47. Available from: http://www.ncbi.nlm.nih.gov/pubmed/21709140.

2. Roychowdhury S, Iyer MK, Robinson DR, Lonigro RJ, Wu Y-M, Cao X, et al. Personalized oncology through integrative high-throughput sequencing: a pilot study. Sci Transl Med 2011;3(111):1-20.

3. Markiewicz A, Wełnicka-Jaśkiewicz M, Skokowski J, Jaśkiewicz J, Szade J, Jassem J, et al. Prognostic Significance of ESR1 Amplification and ESR1 Pvull, CYP2C19*2, UGT2B15*2 Polymorphisms in Breast Cancer Patients. Medeiros R, editor. PLoS One [Internet]. 2013 Aug 8 [cited 2019 Apr 16];8(8):e72219. Available from: https://dx.plos.org/10.1371/journal.pone. 0072219

4. Robinson DR, Wu Y-M, Vats P, Su F, Lonigro RJ, Cao X, et al. Activating ESr1 mutations in hormone-resistant metastatic breast cancer. Nat Genet. 2013;45(12):1446-51.

5. Jeselsohn R. Are we ready to use ESR1 mutations in clinical practice? Breast Care [Internet]. 2017;12(5):309-13 Available from: https://www. karger.com/Article/FullText/481428.

6. Reinert T, Saad ED, Barrios CH, Bines J. Clinical implications of eSR1 mutations in hormone receptor-positive advanced breast Cancer. Front Oncol. 2017;7(March):1-9.

7. Niu J, Andres G, Kramer K, Kundranda M, Alvarez R, Klimant E, et al. Incidence and clinical significance of ESR1 mutations in heavily pretreated metastatic breast cancer patients. Onco Targets Ther [Internet]. 2015 Nov 11 [cited 2019 Apr 18];8:3323. Available from: https://www.dovepress. com/incidence-and-clinical-significance-of-esr1-mutations-in-heavilypretr-peer-reviewed-article-OTT

8. Carson E, Dear R. Advanced breast cancer: An update to systemic therapy. Aust J Gen Pract [Internet]. 2019 May 1 [cited 2020 May 11];48(5):278-83. Available from: https://www1.racgp.org.au/ajgp/2019/may/advancedbreast-cancer-an-update-to-systemic-thera

9. NCCN. NCCN Clinical Practice Guidelines in Oncology : Breast Cancer. Netw Natl Compr Cancer. 2018;1.

10. Widodo I, Dwianingsih EK, Triningsih E, Utoro T, Soeripto. Clinicopathological features of Indonesian breast cancers with different molecular subtypes. Asian Pacific J Cancer Prev. 2014;

11. Akhsan A, Aryandono T. Prognostic factors of locally advanced breast cancer patients receiving neoadjuvant and adjuvant chemotherapy. Asian Pac J Cancer Prev. 2010;11(3):759-761. Available from: http://www. ncbi.nlm.nih.gov/pubmed/21039049.

12. Wilcken N, Hornbuckle J, Ghersi D. Chemotherapy alone versus endocrine therapy alone for metastatic breast cancer. Cochrane Database Syst Rev. 2003;(2):CD002747. Available from: http://www.ncbi.nlm.nih.gov/ pubmed/12804433.

13. Semiglazov VF, Semiglazov VV, Dashyan GA, Ziltsova EK, Ivanov VG, Bozhok AA, et al. Phase 2 randomized trial of primary endocrine therapy versus chemotherapy in postmenopausal patients with estrogen receptor-positive breast cancer. Cancer. 2007;110(2):244-54.

14. Karsono R, Purwanto DJ, Haryono SJ, Karsono B, Sari L, Pratiwi Y, et al. Preoperative Neoadjuvant hormonal therapy and Neoadjuvant chemotherapy for stage $3 \mathrm{~B}$ and 4 breast Cancer patients in Dharmais hospitalNational Cancer Center, Indonesia: a cohort study. Indones J Cancer. 2019;12(4):109.

15. Spring LM, Gupta A, Reynolds KL, Gadd MA, Ellisen LW, Isakoff SJ, et al. Neoadjuvant endocrine therapy for estrogen receptor-positive breast cancer a systematic review and meta-analysis. JAMA Oncol. 2016;2(11):1477-86.

16. Palmieri C, Cleator S, Kilburn LS, Kim SB, Ahn SH, Beresford M, et al. NEOCENT: a randomized feasibility and translational study comparing neoadjuvant endocrine therapy with chemotherapy in ER-rich postmenopausal primary breast cancer. Breast Cancer Res Treat. 2014;148(3):581-90.

17. Alba E, Calvo L, Albanell J, De la Haba JR, Arcusa Lanza A, Chacon Jl, et al. Chemotherapy (CT) and hormonotherapy (HT) as neoadjuvant treatment in luminal breast cancer patients: results from the GEICAM/2006-03, a multicenter, randomized, phase-II study. Ann Oncol. 2012;23(12):3069-74.

18. Saad ED, Katz A, Buyse M. Overall Survival and Post-Progression Survival in Advanced Breast Cancer : A Review of Recent Randomized Clinical Trials. 2018;28(11).

19. Lu H, Chen D, Hu L-P, Zhou L-L, Xu H-Y, Bai Y-H, et al. Estrogen receptor alpha gene polymorphisms, and breast Cancer risk: a case-control study with Meta-analysis combined. Asian Pacific J Cancer Prev. 2014;14(11):6743-9.

20. Bahreini A, Levine K, Santana-Santos L, Benos PV, Wang P, Andersen C, et al. Non-coding single nucleotide variants affecting estrogen receptor binding and activity. Genome Med [Internet]. 2016 [cited 2020 May 11];8(128):1-11. Available from: http://www.pgrr.pitt.edu/pgrr

21. Toy W, Weir H, Razavi P, Lawson M, Goeppert AU, Mazzola AM, et al. Activating ESR1 mutations differentially affect the efficacy of ER antagonists. Cancer Discov. 2017;7(3):277-87.

22. Billam M, Witt AE, Davidson NE. The silent estrogen receptor: can we make it speak? Cancer Biol Ther. 2009;8(6):485-96.

23. Hertz DL, Henry NL, Kidwell KM, Thomas D, Goddard A, Azzouz F, et al. ESR1 and PGR polymorphisms are associated with estrogen and progesterone receptor expression in breast tumors. Physiol Genomics. 2016 Sep 1;48(9):688-98.

24. Gown AM. Current issues in ER and HER2 testing by $\mathrm{HC}$ in breast cancer. Mod Pathol. 2008;21:S8-15.

25. Hu X, Jiang L, Tang C, Ju Y, Jiu L, Wei Y, et al. Association of three single nucleotide polymorphisms of ESR1 with breast cancer susceptibility: a meta-analysis. J Biomed Res. 2017;31(3):213-25.

26. Chandarlapaty S, Chen D, He W, Sung P, Samoila A, You D, et al. Prevalence of ESR1 mutations in cell-free DNA and outcomes in metastatic breast Cancer: a secondary analysis of the BOLERO-2 clinical trial. JAMA Oncol. 2016;2(10):1310-5. 
27. Kuo S, Yang S, You S, Lien H, Lin C-H, Lin P-H, et al. Polymorphisms of ESR1, UGT1A1, HCN1, MAP 3K1, and CYP2B6 are associated with the prognosis of hormone receptor-positive early breast cancer. Oncotarget [Internet]. 2017 Mar 28;8(13):20925-38 Available from: http://www.oncotarget.com/ fulltext/14995.

28. Clatot F, Perdrix A, Augusto L, Beaussire L, Delacour J, Calbrix C, et al. Kinetics, prognostic and predictive values of ESR1 circulating mutations in metastatic breast cancer patients progressing on aromatase inhibitor Oncotarget [Internet]. 2016 Nov 15 [cited 2019 May 9];7(46):74448-59. Available from: http://www.oncotarget.com/fulltext/12950

\section{Publisher's Note}

Springer Nature remains neutral with regard to jurisdictional claims in published maps and institutional affiliations.

- fast, convenient online submission

- thorough peer review by experienced researchers in your field

- rapid publication on acceptance

- support for research data, including large and complex data types

- gold Open Access which fosters wider collaboration and increased citations

- maximum visibility for your research: over $100 \mathrm{M}$ website views per year

At $\mathrm{BMC}$, research is always in progress.

Learn more biomedcentral.com/submissions 